\title{
Pengaruh Penggunaan Metode Jigsaw dan Minat Baca Terhadap Keterampilan Membaca Pemahaman pada Siswa Sekolah Dasar
}

\author{
Ummi Kalsum ${ }^{1}$, Yalvema Miaz², Mega Iswari ${ }^{3}$ \\ ${ }^{1}$ Program Studi Pendidikan Guru Madrasah Ibtidaiyah, Universitas Islam Negeri Sultan Syarif Kasim Riau \\ ${ }^{2,3}$ Universitas Negeri Padang \\ e-mail: sayaummikalsum1993@gmail.com
}

\begin{abstract}
ABSTRAK. This research is motivated by a phenomenon that occurs in the field, namely students have difficulty in reading comprehension. This can be seen from the low scores obtained by students in reading comprehension. This phenomenon makes researchers interested in conducting research. This study aims to obtain information about the effect of using the Jigsaw method and reading interest on reading comprehension skills for elementary school students. This type of research is quantitative research with a quasi-experimental method. Sampling technique The sample in the population is taken using the Simple Random Sampling (SRS) technique. The research data were collected using a reading interest questionnaire and a reading comprehension skill test. The results showed that: (1) the reading comprehension skills of students who were taught using the jigsaw method were higher than the students' reading comprehension skills taught by the conventional method, (2) the reading comprehension skills of students who had high reading interest taught by the jigsaw method were higher. than the reading comprehension skills of students who have high reading interest who are taught by conventional methods, (3) the reading comprehension skills of students who have low reading interest who are taught by the jigsaw method are higher than the reading comprehension skills of students who have low reading interest who are taught by conventional methods, and (4) there is no significant interaction between the jigsawl method and students' reading interest on reading comprehension skills. Based on the research conducted, it can be concluded that reading comprehension skills for elementary school students increase when using the jigsaw method and are associated with reading interest.
\end{abstract}

Kata kunci: ability of teacher, learning plan, 2013 curriculum

\section{PENDAHULUAN}

Pembelajaran bahasa Indonesia mencakup komponen keterampilan berbahasa dan bersastra. Keterampilan ini meliputi empat aspek yaitu keterampilan mendengarkan, berbicara, membaca dan menulis. Pembelajaran bahasa Indonesia bertujuan untuk meningkatkan kemampuan siswa berkomunikasi dalam bahasa Indonesia dengan baik dan benar, baik secara lisan maupun tulisan. Oleh karena itu, penguasaan terhadap keempat aspek kebahasaan tersebut di perlukan untuk mencapai tujuan pembelajaran bahasa Indonesia,salah satunya adalah keterampilan membaca. Membaca adalah salah satu dari empat keterampilan berbahasa, menurut Saddhono (2012) membaca adalah memahami isi ide/gagasan baik tersurat, tersirat maupun tersorot dalam bacaan. Penguasaan dalam membaca ini penting sekali ditanamkan agar nantinya dapat menghasilkan generasi yang memiliki minat baca yang tinggi, sebagaimana yang kita ketahui bahwa membaca adalah jendela dunia.

Keberhasilan belajar siswa dalam mengikuti proses belajar mengajar di sekolah sangat ditentukan oleh penguasaan keterampilan membaca untuk memahami apa yang dibaca serta harus mempunyai minat baca yang tinggi terhadap bahan bacaan yang dibacanya. Menurut Dalman 
(2013:141) mengemukakan bahwa minat baca merupakan dorongan untuk memahami kata demi kata dan isi yang terkandung dalam teks bacaan tersebut, sehingga pembaca dapat memahami halhal yang dituangkan dalam bacaan. Oleh sebab itu, hakekat atau esensi dari membaca adalah pemahaman. Menurut Tarigan (2008) membaca pemahaman (reading for understanding) yang dimaksudkan disini adalah sejenis membaca yang bertujuan untuk memahami bahan bacaan yang telah dipelajari. Senada dengan hal itu, menurut Ekwal (2000) membaca pemahaman merupakan suatu kemampuan yang bertujuan untuk mengenal ide pokok suatu bacaan, mengenal detail yang penting dan mengembangkan imajinasi visual. Hal ini senada dengan indikator dari membaca pemahaman yaitu membaca untuk memperoleh fakta, mendapatkan ide pokok, mendapatkan urutan organisasi tes dan membuat kesimpulan dari bahan bacaan yang dibacanya.

Menurut Evan Ortlieb (2013) menyatakan bahwa pengajaran strategi pemahaman membaca kepada siswa sebagian besar tidak dikenal sebelum tahun (1978/1979) dan penelitian yang telah dilakukannya menyimpulkan bahwa pemahaman membaca bagi siswa dapat ditingkatkan dengan menggunakan strategi yang tepat untuk membaca. Keterampilan membaca dalam pembelajaran tergantung pada peran guru dalam proses pembelajaran, guru seharusnya dapat mengkombinasikan metode-metode dalam proses pembelajaran, metode yang sering dipakai oleh guru adalah metode konvensional. Menurut Alwi dalam Kamus Basar Bahasa Indonesia (2008) mengemukakan bahwa konvensional artinya kebiasaan atau tradisional, dan metode yang paling sering digunakan adalah metode ceramah. Tanya jawab, penungasan dan lainlain.

Berdasarkan hasil wawancara, pada tanggal 3-4 Agustus 2016 dengan beberapa guru di kelas VI diperoleh informasi bahwa keterampilan membaca pemahaman bagi siswa tergolong cukup, hal ini dapat dilihat hasil wawancara dari beberapa guru diantaranya (1) guru masih menggunakan metode konvensional seperti penungasan, dan tanya jawab, pada keterampilan membaca guru memberikan instruksi kepada siswa untuk membaca kemudian guru bertanya kesimpulan dari bahan bacaan yang dibacanya, (2) siswa masih kurang memahami bahan bacaan yang dibacanya seperti siswa kurang mampu mengungkapkan kembali bahan bacaan yang dibacanya sehingga kemampuan membaca pemahaman mereka masih berkategori cukup, (3) saat membaca siswa masih banyak yang bertanya dimana letak ide pokok sehingga siswa sulit untuk memahami bahan bacaan yang dibacanya, (4) siswa kurang mempunyai minat baca, siswa membaca apabila akan diadakan ujian (5) siswa kurang sungguh-sungguh dalam melakukan kegiatan membaca misalnya saat membaca siswa sering keluar masuk kelas dan menganggu teman yang sedang membaca dan siswa membaca apabila ada perintah dari guru

Berdasarkan permasalahan diatas, Agar proses pembelajaran menjadi lebih efektif, sebaiknya guru harus memperhatikan metode-metode yang bisa membuat siswa lebih mempunyai minat baca dalam belajar. Peneliti memiliki gagasan untuk memberikan solusi terhadap permasalahan tersebut. Salah satu metode pembelajaran yang dapat digunakan untuk meningkatkan minat baca sehingga keterampilan membaca pemahaman siswa menjadi lebih baik adalah dengan menggunakan metode jigsaw. Menurut Abidin (2012) metode jigsaw merupakan metode pembelajaran membaca yang mendorong siswa aktif dan saling membantu dalam menguasai materi pelajaran untuk mencapai prestasi yang maksimal. Kegiatan belajar dengan menggunakan metode Jigsaw membaca menggabungkan kegiatan membaca, menulis, mendengarkan dan berbicara sehingga selain meningkatkan kemampuan membaca dengan disertai pemahaman yang tinggi, juga dapat meningkatkan tiga keterampilan berbahasa yang lain.

\section{METODOLOGI}

Jenis penelitian ini adalah penelitian kuantitatif, Metode yang digunakan dalam penelitian ini adalah metode eksperimen, jenis eksperimen ini adalah eksperimen semu (Quasy experiment) Penelitian ini terdiri atas tiga variabel. Pertama, Variabel independen (variabel bebas) adalah 
variabel yang menyebabkan perubahan terhadap variabel dependen. Kedua, Variabel dependen (variabel terikat) adalah variabel yang dipengaruhi oleh variabel independen. Ketiga. Dalam penelitian ini teknik pengumpulan data yang digunakan adalah berupa hasil tes keterampilan membaca pemahaman siswa dan angket pada minat baca. Setelah data penelitian ditetapkan, maka dilakukan teknik pengumpulan data. Sebelum angket diberikan kepada siswa peneliti melakukan uji coba instrument kepada validator. Hal ini bertujuan agar instrumen yang digunakan sudah sesuai dan dapat menentukan tingkat kesukaran dan daya pembeda. Instrument yang diperlukan dalam penelitian ini adalah Rencana Pelaksanaan Pembelajaran (RPP), angket dan tes keterampilan membaca pemahaman.

Tabel 1. Kisi-Kisi Angket Minat Baca

\begin{tabular}{lll}
\hline Variabel & \multicolumn{1}{c}{ Indikator } & \multicolumn{1}{c}{ Sub Indikator } \\
\hline Minat Baca & $\begin{array}{l}\text { Frekuensi dan kuantitas } \\
\text { membaca } \\
\text { Kuantitas } \\
\text { bacaan }\end{array}$ & $\begin{array}{l}\text { Menyediakan waktu untuk membaca } \\
\text { Memiliki kesadaran dan minat yang tinggi } \\
\end{array}$ \\
& terhadap membaca \\
& Membeli buku yang menarik minat anak \\
& Tukar buku dengan teman \\
& Kegiatan membaca sebagai kegiatan sehari- \\
& hari \\
& Ajak anak ke toko buku atau perpustakaan \\
& \\
& Dorong anak untuk bercerita tentang apa \\
& yang didengar dan dibacanya \\
& Pemilihan bahan bacaan yang baik
\end{tabular}

\section{TEMUAN DAN DISKUSI}

Penelitan ini dilakukan sesuai dengan prosedur penelitian eksperimen. Pada prinsipnya, penelitian eksperimen bertujuan untuk melihat hasil tes keterampilan membaca pemahaman bagi siswa menggunakan metode jigsaw dan minat baca siswa. Hasil penelitian yang dilakukan peneliti adalah sebagai berikut.

Tabel 3. Uji Normalitas Hasil Tes Keterampilan Membaca Pemahaman Bagi Siswa di Sekolah Eksperimen dan Kontrol

\begin{tabular}{lcccccc}
\hline & \multicolumn{3}{c}{ Kolmogorov-Smirnov $^{\mathrm{a}}$} & \multicolumn{4}{c}{ Shapiro-Wilk } \\
& Statistic & $\mathrm{df}$ & Sig. & Statistic & $\mathrm{df}$ & Sig. \\
\hline Eksperimen & .127 & 46 & .062 & .955 & 46 & .075 \\
Kontrol & .140 & 46 & .024 & .953 & 46 & .062 \\
& & & & & & \\
\hline
\end{tabular}

Berdasarkan hasil analisis data uji normalitas sebagaimana yang terlihat pada tabel di atas, diketahui nilai signifikan untuk tes keterampilan membaca pemahaman sekolah eksperimen sebesar 0.075 dan sekolah kontrol sebesar 0.062. jika nilai signifikan dari masing-masing sekolah dibandingkan dengan alfa $(\boldsymbol{\alpha}=0.05)$ dimana terlihat signifikan lebih besar dari pada alpha. Dengan demikian dapat dikatakan bahwa data hasil penelitian untuk tes keterampilan membaca pemahaman berdistribusi normal. 
Tabel 4. Uji Normalitas Hasil Tes Keterampilan Membaca Pemahaman Bagi Siswa Berminat Baca Tinggi di Sekolah Eksperimen dan Kontrol

\begin{tabular}{lcccccc}
\hline & \multicolumn{3}{c}{ Kolmogorov-Smirnov a } & \multicolumn{3}{c}{ Shapiro-Wilk } \\
& Statistic & $\mathrm{df}$ & Sig. & Statistic & $\mathrm{df}$ & Sig. \\
\hline MBT_Eksperimen & .155 & 24 & .140 & .941 & 24 & .175 \\
MBT_Kontrol & .229 & 24 & .002 & .927 & 24 & .083 \\
\hline
\end{tabular}

Berdasarkan hasil analisis data uji normalitas sebagaimana yang terlihat pada tabel di atas, diketahui nilai signifikan untuk tes keterampilan membaca pemahaman bagi siswa berminat baca tinggi di sekolah eksperimen sebesar 0.175 dan sekolah kontrol sebesar 0.083. jika nilai signifikan dari masing-masing sekolah dibandingkan dengan alfa $(\boldsymbol{\alpha}=0.05)$ dimana terlihat signifikan lebih besar dari pada alpha. Dengan demikian dapat dikatakan bahwa data hasi penelitian untuk tes keterampilan membaca pemahaman bagi siswa berminat baca tinggi di sekolah eksperimen dan kontrol berdistribusi normal.

Tabel 5. Uji Normalitas Hasil Tes Keterampilan Membaca Pemahaman Bagi Siswa Berminat Baca Rendah di Sekolah Eksperimen dan Kontrol

\begin{tabular}{lcccrrr}
\hline & \multicolumn{2}{c}{ Kolmogorov-Smirnova } \\
& Statistic & $\mathrm{df}$ & Sig. Statistic & $\mathrm{df}$ & Sig. \\
\hline MBR_Eksperimen & .170 & 21 & .114 & .921 & 21 & .090 \\
MBR_Kontrol & .187 & 21 & .054 & .915 & 21 & .069 \\
a. Lilliefors Significance Correction & & & & & \\
\hline
\end{tabular}

Berdasarkan hasil analisis data uji normalitas sebagaimana yang terlihat pada tabel di atas, diketahui nilai signifikan untuk tes keterampilan membaca pemahaman bagi siswa berminat baca rendah di sekolah eksperimen sebesar 0.090 dan sekolah kontrol sebesar 0.069. jika nilai signifikan dari masing-masing sekolah dibandingkan dengan alfa $(\boldsymbol{\alpha}=0.05)$ dimana terlihat signifikan lebih besar dari pada alpha. Dengan demikian dapat dikatakan bahwa data hasi penelitian untuk tes keterampilan membaca pemahaman bagi siswa berminat baca tinggi di sekolah eksperimen dan kontrol berdistribusi normal.

Berdasarkan hasil analisa data untuk uji homogenitas sebagaimana terihat pada tabel 6 diketahui bahwa hasil homogenitas keterampilan membaca pemahaman di sekolah eksperimen dan kelas kontrol signya adalah 0.223 . jika nilai signifikan dibandingkan dengan alpha $\alpha(0,05)$ maka terlihat nilai signifikan lebih besar dari pada alpha. Dengan demikian dapat dikatakan bahwa hasil penelitian memiliki variansi yang sama atau homogen. Berdasarkan hasi analisa data untuk uji homogenitas sebagaimana terihat pada tabel 7 diketahui bahwa hasil homogenitas keterampilan membaca pemahaman bagi siswa berminat baca tinggi di sekolah eksperimen dan kelas kontrol signya adalah 0.354 . jika nilai signifikan dibandingkan dengan alpha $\alpha(0,05)$ maka terlihat nilai signifikan lebih besar dari pada alpha. Dengan demikian dapat dikatakan bahwa hasil penelitian memiliki variansi yang sama atau homogeny

Berdasarkan hasi analisa data untuk uji homogenitas sebagaimana terihat pada tabel 8 diketahui bahwa hasil homogenitas keterampilan membaca pemahaman bagi siswa berminat baca rendah di sekolah eksperimen dan kelas kontrol signya adalah 0.170. jika nilai signifikan dibandingkan dengan alpha $\alpha(0,05)$ maka terlihat nilai signifikan lebih besar dari pada alpha. Dengan demikian dapat dikatakan bahwa hasil penelitian memiliki variansi yang sama atau homogen. Hasil perhitungan pada tabel 9 menunjukkan bahwa nilai $t_{\text {hitung }} 2.517$ dan 2.512 serta 
nilai Sig nya 0.14. sehingga nilai signya $0.014<0.05$ maka $\mathrm{H}_{0}$ ditolak dan $\mathrm{H}_{1}$ diterima. Hal ini berarti bahwa keterampilan membaca pemahaman bagi siswa yang diajar dengan metode jigsaw lebih baik daripada keterampilan membaca pemahaman bagi siswa yang diajar dengan metode konvensional.

Hasil perhitungan pada tabel 10 menunjukkan bahwa nilai $\mathrm{t}_{\text {hitung }} 2.044$ dan 2.050 serta nilai Sig nya 0.046. sehingga nilai signya $0.046<0.05$ maka $\mathrm{H}_{0}$ ditolak dan $\mathrm{H}_{1}$ diterima. Sehingga dapat ditarik kesimpulan bahwa hasil tes keterampilan membaca pemahaman bagi siswa yang memiliki minat baca tinggi yang diajarkan dengan metode jigsaw lebih tinggi dari hasil tes keterampilan membaca pemahaman bagi siswa yang memiliki minat baca tinggi yang diajarkan dengan metode konvensional pada taraf signifikan 0.05. Hasil perhitungan pada tabel 11 menunjukkan bahwa nilai thitung 3.421 dan 3.449 serta nilai Sig nya 0.001. sehingga nilai signya $0.001<0.05$ maka H0 ditolak dan H1 diterima. Sehingga dapat ditarik kesimpulan bahwa hasil tes keterampilan membaca pemahaman bagi siswa yang memiliki minat baca rendah yang diajarkan dengan metode jigsaw lebih tinggi dari hasil tes keterampilan membaca pemahaman bagi siswa yang memiliki minat baca rendah yang diajarkan dengan metode konvensional pada taraf signifikan 0.05

Tabel 12. Hasil Analisis Varian untuk Interaksi Metode Jigsaw dengan Minat Baca

\begin{tabular}{|c|c|c|c|c|c|}
\hline \multirow[b]{2}{*}{ Source } & \multicolumn{5}{|c|}{ Mean } \\
\hline & Type III Sum of Squares & df & & $\mathbf{F}$ & Sig. \\
\hline Corrected Model & $23558.259^{a}$ & 3 & 7852.753 & 71.654 & .000 \\
\hline Intercept & 416773.864 & 1 & 416773.864 & $3.803 \mathrm{E} 3$ & .000 \\
\hline Kelas & 1730.154 & 1 & 1730.154 & 15.787 & .000 \\
\hline Minat_BAca & 21333.872 & 1 & 21333.872 & 194.666 & .000 \\
\hline $\begin{array}{l}\text { Kelas* } \\
\text { Minat_BAca }\end{array}$ & 197.541 & 1 & 197.541 & 1.803 & .183 \\
\hline Error & 9753.698 & 89 & 109.592 & & \\
\hline Total & 467297.000 & 93 & & & \\
\hline Corrected Total & 33311.957 & 92 & & & \\
\hline
\end{tabular}

a. R Squared $=.707$ (Adjusted R Squared $=.697$ )

Hasil perhitungan anava dua jalur untuk pengujian hipotesis keempat terlihat pada tabel diatas pada metode jigsaw minat baca diperoleh 0.183, ini berarti bahwa nilai Sig lebih besar dari nilai $\boldsymbol{\alpha} 0.05$ maka hipotesis nol (H0) diterima dan H1 ditolak. Sehingga tidak terdapat interaksi yang signifikan antara metode jigsaw dengan minat baca terhadap keterampilan membaca pemahaman bagi siswa pada mata pelajaran bahasa Indonesia.

\section{PEMBAHASAN}

\section{Keterampilan Membaca Pemahaman bagi Siswa yang Diajar dengan Metode Jigsaw dan metode Konvensional}

Berdasarkan hasil signifikan dari normalitas, keterampilan membaca pemahaman pada siswa yang diajar dengan metode jigsaw (tanpa memperhatikan tingkatan minat baca) adalah 0.075 atau lebih tinggi dari hasil tes keterampilan membaca pemahaman pada siswa yang pada siswa yang diajar dengan metode konvensional sebesar 0.062. Berdasarkan hasil analisis data dapat diinterpretasikan bahwa metode jigsaw lebih baik dibandingkan dengan metode konvensional. Hasil analisis data juga diperkuat dengan hasil pengujian hipotesis pertama dengan menggunakan uji t diperoleh varians gabungan kedua sampel adalah $0.014<0.05$ maka H0 ditolak dan H1 
diterima. Hal ini berarti bahwa keterampilan membaca pemahaman bagi siswa yang diajar dengan metode jigsaw lebih baik daripada keterampilan membaca pemahaman bagi siswa yang diajar dengan pendekatan konvensional.

Penelitian ini telah mengungkapkan bahwa metode jigsaw memberikan pengaruh yang positif terhadap keterampilan membaca pemahaman. Pelaksanaan metode jigsaw berhasil mempengaruhi keterampilan membaca pemahaman. Kenyataannya hasil tes keterampilan membaca pemahaman yang mendapat perlakuan dengan menggunakan metode jigsaw menunjukkan peningkatan secara signifikan dibandingkan dengan siswa yang tidak mendapatkan perlakuan. Oleh karena itu, keunggulan metode jigsaw dapat ditemui dan bermanfaat dalam proses pembelajaran. Menurut Abidin (2012: 166) Metode jigsaw merupakan metode pembelajaran membaca yang mendorong siswa aktif dan saling membantu dalam menguasai materi pelajaran untuk mencapai prestasi yang maksimal. Kegiatan belajar jigsaw membaca menggabungkan kegiatan membaca, menulis, mendengarkan dan berbicara sehingga selain meningkatkan kemampuan membaca siswa, juga dapat meningkatkan tiga keterampilan berbahasa dalam pembelajaran bahasa Indonesia

Berbeda dengan metode jigsaw, metode konvensional menempatkan siswa sebagai objek belajar yang berperan sebagai penerima informasi secara pasif. Pada umumnya, penyampaian pembelajaran menggunakan metode ceramah, tanyajawab, dan penugasan. Guru selalu mendominasi kegiatan pembelajaran, sedangkan siswa lebih banyak menerima dari guru. Hal ini sesuai dengan pendapat Djaafar (2001:3) yang menyatakan bahwa metode belajar konvensional merupakan metode yang berorientasi pada guru, hampir seluruh kegiatan pembelajaran dikendalikan penuh oleh guru.

Hal ini dapat dilihat pada saat penelitian berlangsung, siswa yang diajar dengan pendekatan konvensional menunjukkan sikap pasif. Siswa mendengarkan penjelasan dari guru, mencatat, serta menjawab pertanyaan guru jika guru bertanya. Tidak punya inisiatif untuk melakukan komunikasi dengan sesama siswa untuk membahas hal-hal yang berhubungan dengan materi pelajaran yang sedang dipelajari. Kemudian mengerjakan latihan yang ditugaskan oleh guru. Berdasarkan uraian di atas, dari hasil temuan penelitian dan analisis data yang telah dilakukan dapat disimpulkan bahwa metode jigsaw memberikan pengaruh terhadap keterampilan membaca pemahaman. Hal ini dibuktikan dari signifikan siswa sekolah eksperimen yang diajar dengan metode jigsaw lebih tinggi dibandingkan dengan kelas kontrol yang diajar dengan metode konvensional.

\section{Keterampilan Membaca Pemahaman bagi Siswa yang Memiliki Minat Baca tinggi yang diajar dengan Metode Jigsaw dan Pendekatan Konvensional}

Berdasarkan hasil signifikan dari normalitas, keterampilan membaca pemahaman bagi siswa yang memiliki minat baca tinggi sebesar 0.175 lebih tinggi dibandingkan dengan siswa yang diajar dengan pendekatan konvensional yang memiliki minat baca tinggi sebesar 0.083. Hasil analisis data juga diperkuat dengan hasil pengujian hipotesis kedua dengan menggunakan uji $\mathrm{t}$ diperoleh varians gabungan kedua sampel adalah $0.046<0.05$ maka H0 ditolak dan H1 diterima. Hal ini berarti bahwa keterampilan membaca pemahaman bagi siswa yang memiliki minat baca tinggi yang diajar dengan metode jigsaw lebih baik daripada keterampilan membaca pemahaman bagi siswa yang memiliki minat baca tinggi yang diajar dengan pendekatan konvensional.

Pembelajaran menggunakan metode jigsaw mampu meningkatkan keterampilan membaca pemahaman bagi siswa yang memiliki minat baca yang tinggi. Hal ini dikarenakan metode jigsaw merupakan metode pembelajaran membaca yang mendorong siswa aktif dan saling membantu dalam menguasai materi pelajaran untuk mencapai prestasi yang maksimal. Siswa yang memiliki minat baca tinggi yang diajar dengan metode jigsaw belajar berinteraksi dengan kelompok dan saling memberikan informasi kepada sesama anggota kelompok. Akibatnya siswa yang memiliki minat baca tinggi lebih bersemangat dalam belajar. Berdasarkan uraian di atas dapat disimpulkan 
bahwa hasil tes keterampilan membaca pemahaman bagi siswa berminat baca tinggi yang diajar dengan metode jigsaw lebih baik dari siswa yang bermotivasi tinggi yang diajar dengan pendekatan konvensional.

\section{Keterampilan membaca pemahaman Siswa yang Memiliki Minat Baca Rendah yang diajar dengan Metode Jigsaw dan Pendekatan Konvensional}

Berdasarkan hasil signifikan dari normalitas, keterampilan membaca pemahaman bagi siswa yang memiliki minat baca rendah sebesar 0.090 lebih tinggi dibandingkan dengan siswa yang diajar dengan metode konvensional yang memiliki minat baca tinggi sebesar 0.069. Hasil analisis data juga diperkuat dengan hasil pengujian hipotesis ketiga dengan menggunakan uji $\mathrm{t}$ diperoleh varians gabungan kedua sampel adalah $0.001<0.05$ maka H0 ditolak dan H1 diterima. Hal ini berarti bahwa keterampilan membaca pemahaman bagi siswa yang memiliki minat baca rendah yang diajar dengan metode jigsaw lebih baik daripada keterampilan membaca pemahaman bagi siswa yang memiliki minat baca rendah yang diajar dengan metode konvensional

\section{Interaksi antara Minat Baca dan Metode Jigsaw dalam Mempengaruhi Keterampilan Membaca Pemahaman}

Hasil perhitungan pengujian hipotesis keempat dengan menggunakan uji Anava Dua Arah adalah $0.183>0.05$ maka H0 diterima dan H1 ditolak. Hal ini berarti bahwa tidak terdapat interaksi yang signifikan antara metode jigsaw dengan minat baca siswa terhadap keterampilan membaca pemahaman. Berdasarkan uraian di atas dapat disimpulkan bahwa penelitian ini tidak terjadi interaksi antara metode jigsaw dan minat baca terhadap keterampilan membaca pemahaman bagi siswa di kelas VI SDN di gugus II Kecamatan Nanggalo Padang.

\section{KESIMPULAN}

Hasil tes keterampilan membaca pemahaman bagi siswa yang diajar dengan metode jigsaw lebih tinggi dari hasil tes keterampilan membaca pemahaman bagi siswa yang diajar dengan metode konvensional. Hasil tes keterampilan membaca pemahaman bagi siswa dengan minat baca tinggi yang diajar dengan metode jigsaw lebih tinggi dibandingkan dengan siswa yang memiliki minat baca tinggi yang diajar dengan metode konvensional. Hasil tes keterampilan membaca pemahaman bagi siswa dengan minat baca rendah yang diajar dengan metode jigsaw lebih tinggi dibandingkan dengan siswa yang memiliki minat baca rendah yang diajar dengan metode konvensional. Hasil penelitian ini tidak menunjukkan terdapat interaksi antara metode jigsaw dengan minat baca dalam proses pembelajaran.

\section{REFERENSI}

Abidin, Yunus, 2012. Pembelajaran Bahasa Berbasis Pendidikan Karakter. Bandung: Rafika Adimata

Adam, Francis Hull. 2013. Using jigsaw technique as an effective way of promoting co-operative learning among primary six pupils in fijai. Holy Child College of Education, Takoradi Ghana. Di akses tanggal 9 Agustus 2016

Alwi, dkk. 2008. Kamus Besar Bahasa Indonesia. Jakarta: Gramedia

Agustina. 2008. Pengajaran Keterampilan Membaca. Bandung:Rekayasa Sains

Ahuja, Pramila. 2010. Membaca Secara Efektif dan Efisien. Bandung: Kiblat Utama

Arikunto, Suharsimi. 2010.Prosedur Penelitian Suatu Pendekatan Praktik.Jakarta: Rineka Cipta

Dalman, 2013. Keterampilan membaca. Jakarta: pt raja grafindo persada

Djafar, tengku zahara. 2001. Konstribusi strategi pembelajaran terhadap hasil belajar. Padang: unp 
Ekwal. 2000. Kemampuan dasar guru dalam proses belajar mengajar. Bandung: remaja rosdakarya Fuzidri, 2014. Peningkatan keterampilan membaca pemahaman mellaui model pembelajaran kooperatif tipe circ peserta didikkelas viii mtsn kamang kabupaten agam. Padang: unp

Gulo, 2002. Strategi belajar mengajar. Jakarta: grafindo

Hamdayama, Jumanta. 2014. Model dan Metode Pembelajaran Kreatif dan Berkarakter. Bogor: Ghalia Indonesia

Irianto, Agus. 2010. Statistik. Jakarta: Kencana

Lubis,Syahron. 2009. Metodologi Penelitian Pendidikan, Padang: Sukabina Press

Masgami, 2011. Peningkatan kemampuan membaca pemahaman melalui model pembelajaran kooperatif tipe jigsaw peserta didikkelas vii a smp negeri 6 bangkinang. Padang: unp

Nurhadi, 2008. Membaca Cepat dan Efektif. Bandung: Sinar Saru Nalgasendo

Nurgiyanto, Burhan. 2012. Penilaian Pembelajaran Bahasa Berbasis Kompetensi, Yogyakarta: BPFP Yogyakarta

Ortlieb, Evan. 2013. Using Anticipatory Reading Guides to Improve Elementary Students' Comprehension. Monash University, Australia. Di akses tanggal 9 Agustus 2015

Rahim, Farida. 2008. Pengajaran Membaca di Sekolah Dasar. Jakarta: Bumi Aksara

Ridwan,2012. Dasar-dasar Statistik. Bandung: Alfabeta

Saddhono, Kundharu, dkk. 2012. Meningkatkan Keterampilan Berbahasa Indonesia (Teori dan Aplikasi). Bandung: Karya Putra Darwati

Slameto, 2010. Belajar dan Faktor-Faktor yang Mempengaruhinya, Jakarta:Rineka cipta

Somadayo, Samsu. 2011.Stategi dan Teknik Pembelajaran Membaca. Yogyakarta :Graha Ilmu

Sudjana, 2005. Metode Statistik. Bandung: Alfabeta

Sukmadinata, Nana Syaodih. 2006, Metode Penelitian Pendidikan,Bandung: PT Remaja Rosdakarya

Sugiyono, 2012. Metode Penelitian Kuantitatif Kualitatif R\&D. Bandung: Alfabeta.

Sumarna, Surapranata, 2004. Analisis Validitas, Realibilitas dan Inerpretasi Hasil Tes. Bandung: Remaja Rosda Karya

Tampubolon, D.P. 2008. Kemampuan Membaca, Teknik Membaca Efektif dan Efisien (Edisi Revisi). Bandung: Angkasa

Tarigan, Henry Guntur. 2008. Membaca Sebagai Suatu Keterampialn Berbahasa (edisi revisi) Bandung: Angkasa

, 2011. Membaca dalam kehidupan (edisi Revisi). Bandung: Angkasa

Viora, Dwi. 2014. Konstribusi Minat Baca dan Penguasaan Kosakata Terhadap Kemampuan Membaca Pemahaman Peserta didikKelas XI SMA Negeri 1 Kouk Kabupaten Kampar Provinsi Riau.Padang: UNP

Yusrizal. 2012. Peningkatan Keterampilan Membaca Pemahaman Teks Fiksi Peserta didik Kelas VII C Madrasah tsanawiyah negeri menggunakan model pembelajaran kooperatif tipe jigsa. Padang: UNP 